\title{
Antimicrobial activity and cytotoxicity of the ethanol extract, fractions and eight compounds isolated from Eriosema robustum (Fabaceae)
}

Maurice D Awouafack ${ }^{1,2}$, Lyndy J McGaw', Sebastian Gottfried ${ }^{3}$, Roukayatou Mbouangouere ${ }^{2}$, Pierre Tane ${ }^{2}$, Michael Spiteller ${ }^{3}$ and Jacobus $N$ Eloff $^{*}$

\begin{abstract}
Background: The aim of this study was to evaluate the antimicrobial activity and the cytotoxicity of the ethanol crude extract, fractions and isolated compounds from the twigs of Eriosema robustum, a plant used for the treatment of coughs and skin diseases.

Methods: Column chromatographic and spectroscopic techniques were used to isolate and identify eight compounds, robusflavones A (1) and B (2), orostachyscerebroside A (3), stigmasterol (4), 1-O-heptatriacontanoyl glycerol (5), eicosanoic acid (6), 3-O- $\beta$-D-glucopyranoside of sitosterol (7) and 6-prenylpinocembrin (8), from E. robustum. A two-fold serial microdilution method was used to determine the minimum inhibitory concentration (MIC) against fungi and bacteria, and the 3-(4,5-dimethylthiazolyl-2)-2,5-diphenyltetrazolium bromide reduction assay was used to evaluate the cytotoxicity.
\end{abstract}

Results: Fraction B had significant antimicrobial activity against Aspergillus fumigatus and Cryptoccocus neoformans (MIC $0.08 \mathrm{mg} / \mathrm{ml}$ ), whilst the crude extract and fraction A had moderate activity against A. fumigatus and Candida albicans (MIC $0.16 \mathrm{mg} / \mathrm{ml}$ ). Fraction A however had excellent activity against Staphylococcus aureus (MIC $0.02 \mathrm{mg} / \mathrm{ml}$ ), Enterococcus faecalis and Escherichia coli (MIC $0.04 \mathrm{mg} / \mathrm{ml}$ ). The crude extract had significant activity against S. aureus, E. faecalis and E. coli. Fraction B had good activity against E. faecalis and E. coli (MIC $0.08 \mathrm{mg} / \mathrm{ml}$ ). All the isolated compounds had a relatively weak antimicrobial activity. An MIC of $65 \mu \mathrm{g} / \mathrm{ml}$ was obtained with robusflavones A (1) and B (2) against C. albicans and A. fumigatus, orostachyscerebroside A (3) against A. fumigatus, and robusflavone B (2) against C. neoformans. Compound 8 had the best activity against bacteria (average MIC $55 \mu \mathrm{g} / \mathrm{ml}$ ). The 3 fractions and isolated compounds had $L C_{50}$ values between 13.20 to $>100 \mu \mathrm{g} / \mathrm{ml}$ against Vero cells yielding selectivity indices between 0.01 and 1.58 .

Conclusion: The isolated compounds generally had a much lower activity than expected based on the activity of the fractions from which they were isolated. This may be the result of synergism between different compounds in the complex extracts or fractions. The results support the traditional use of E. robustum to treat infections. The crude extract had a good activity and low preparation cost, and may be useful in topical applications to combat microbial infections.

Keywords: Eriosema robustum, Fabaceae, Flavonoids, Antimicrobial, Cytotoxicity

\footnotetext{
* Correspondence: kobus.eloff@up.ac.za

${ }^{1}$ Phytomedicine Programme, Department of Paraclinical Sciences, Faculty of Veterinary Science, University of Pretoria, Private Bag X04, Onderstepoort 0110, South Africa

Full list of author information is available at the end of the article
} 


\section{Background}

The need for new, effective and affordable drugs to treat microbial diseases in the developing world is one of the issues facing global health today. Available drugs for the treatment of these diseases are limited by factors ranging from microbe resistance to safety, compliance and cost. The use of medicinal plants for curative purposes is as old as mankind and can be traced from the beginning of civilisation. The interaction between man and his environment is such that his food, shelter, the diseases that afflict him and the cure of such diseases are all within the environment. Thus, man uses his environment and the resources of nature to combat diseases that afflict him. Consequently over many centuries, people of various countries of the world have embarked on what is now known as traditional medicine [1]. It is estimated that plants are still a major source of primary healthcare for more than $60 \%$ of the world's population.

Eriosema robustum, a member of Fabaceae family, is a perennial non-climbing shrub with yellow flowers native to Burundi, Ethiopia, Kenya, Rwanda, Tanzania, Uganda, Democratic Republic of Congo and Cameroon [2]. It is used traditionally for the treatment of coughs in East Africa [3] and skin diseases in the Western Region of Cameroon. Previous phytochemical study on this species led to the isolation and characterization of two flavonoids, robusflavones $\mathrm{A}$ and $\mathrm{B}$, and five known compounds [4]. As part of our ongoing study for bioactive secondary metabolites from species of the Fabaceae family [4-6], we have re-investigated the ethanol extract of the twigs of E. robustum using bioassay-guided fractionation. To investigate the potential use of an extract, fractions or compounds, the cellular toxicity also has to be determined. The therapeutic index, that is, ratio of activity against microorganisms to toxicity to animal cells, is important.

We report herein the antimicrobial activity and cytotoxicity of the crude extract, fractions and the isolated compounds (1-8). This is also the first report on the isolation of a cerebroside, orostachyscerebroside A (3), from the genus Eriosema.

\section{Methods}

\section{Plant material}

The twigs of E. robustum were collected in Dschang, Western Region of Cameroon, in December 2011 and identified at the Cameroon National Herbarium in Yaoundé where a specimen was deposited under a voucher number 35291/HNC.

\section{Extraction and isolation}

The dried and powdered twigs of E. robustum $(2 \mathrm{~kg})$ were extracted for three days in ethanol (10 litres $\times 3$ times) to yield the crude extract (115 g) after filtration and solvent evaporation using a rotary evaporator. Part of this extract ( $5 \mathrm{~g}$ ) was subjected to a silica gel column chromatography eluted with n-hexane (Hex), chloroform $\left(\mathrm{CHCl}_{3}\right)$, ethyl acetate (EtOAc) and methanol $(\mathrm{MeOH})$ in increasing polarity to give 40 fractions of $500 \mathrm{ml}$ each that were combined after monitoring with comparative thin layer chromatography (Co-TLC) into 3 fractions: A [(0.9 g, $\mathrm{Hex}-\mathrm{CHCl}_{3}(100: 0,4: 1,3: 2,1: 4)$ and $\mathrm{CHCl}_{3}-$ EtOAc (100:0, 4:1)], B [(0.7 g, $\mathrm{CHCl}_{3}-\operatorname{EtOAc}(4: 1,3: 2,1: 4)$ and $\mathrm{C}\left[\left(2.5 \mathrm{~g}, \mathrm{CHCl}_{3}-\right.\right.$ EtOAc (1:4) and EtOAc - MeOH (100:0, 3:7, 0:100)]. Fraction $\mathrm{C}$ did not have as many active antimicrobial constituents separated by TLC in bioautography as fractions A and B, and was not further investigated.

Fraction B was subjected to purification applying silica gel column chromatography eluted with n-hexane, acetone and methanol in order of increasing polarity to yield 50 fractions of $150 \mathrm{ml}$ each which were combined in subfractions after monitoring with Co-TLC. Subfractions $\mathrm{F}_{25-26}$ and $\mathrm{F}_{27-30}$ eluted with $\mathrm{n}$-hexane: acetone (17:3) gave compounds 2 (9 mg), 4 (8 mg) and 6 (12 mg). Subfractions $\mathrm{F}_{20-26}$ eluted with n-hexane: acetone $(7: 3,3: 2)$ and $F_{27-35}$ eluted with $n$-hexane: acetone (11:9, 1:9) were similarly subjected to further silica gel column chromatography eluted with n-hexane, ethyl acetate, methanol in gradient polarity followed by preparative TLC and Sephadex LH-20 to yield 1 (4 mg), 3 (10 mg), 5 (7 mg) and 7 (9 mg).

Fraction A was subjected to Sephadex LH-20 to remove chlorophyll and the eluate was concentrated and fractionated using similar silica gel column techniques as described above for fraction $B$ to give mainly 4 (3 $\mathrm{mg}$ ) and 8 (17 $\mathrm{mg})$.

Orostachyscerebroside $A$ (3): colourless amorphous; ${ }^{1} \mathrm{H}$ NMR (DMSO- $d_{6}, 400 \mathrm{MHz}$ ): $\delta 4.38$ (br.t, $4.0 \mathrm{~Hz}, \mathrm{H}-1_{\mathrm{b}}$ ), 4.58 (br.t, $4.0 \mathrm{~Hz}, \mathrm{H}-1_{\mathrm{a}}$ ), 4.08 ( $\left.m, \mathrm{H}-2\right), 3.76$ ( $\left.m, \mathrm{H}-3\right)$, 3.70 ( $m, \mathrm{H}-4)$, 1.86-2.02 (2H, $m, \mathrm{H}-5), 5.63(8 \mathrm{H}, m, \mathrm{H}-6 /$ $\left.\mathrm{H}-7 / \mathrm{H}-10 / \mathrm{H}-11 / \mathrm{H}^{-6} 6^{\prime} / \mathrm{H}-7^{\prime} / \mathrm{H}-9^{\prime} / \mathrm{H}-10^{\prime}\right), 1.23-1.33(8 \mathrm{H}$, $\left.m, \mathrm{H}-8 / \mathrm{H}-12 / \mathrm{H}-5^{\prime} / \mathrm{H}^{\prime} 1^{\prime}\right)$, 1.40-1.65 (2H, $\left.m, \mathrm{H}-9\right), 1.24-$ 1.31 ( $20 \mathrm{H}, m, \mathrm{H}-13$ to $\mathrm{H}-22), 1.50$ (4H, $\left.m, \mathrm{H}-23 / \mathrm{H}-19^{\prime}\right)$, $0.84\left(6 \mathrm{H}, t, 4.0 \mathrm{~Hz}, \mathrm{H}-24 / \mathrm{H}-20^{\prime}\right), 3.80$ (m, H-2'), 1.26 $\left(m, \mathrm{H}-3^{\prime}{ }_{\mathrm{a}}\right), 2.02\left(m, \mathrm{H}-3^{\prime}{ }_{\mathrm{b}}\right), 1.02\left(2 \mathrm{H}, m, \mathrm{H}-4{ }^{\prime}\right), 1.02-$ $1.20\left(2 \mathrm{H}, m, \mathrm{H}-8^{\prime}\right), 1.20-1.33\left(14 \mathrm{H}, m, \mathrm{H}-12^{\prime}\right.$ to $\left.\mathrm{H}-18^{\prime}\right)$, $4.12\left(d, 8.0 \mathrm{~Hz}, \mathrm{Glc}-1^{\prime \prime}\right), 3.32$ (m, H-2"), 4.96 (m, H-3"), 3.60 (m, H-4"), 3.03 (m, H-5"), 3.38 (m, H-6" ${ }_{\mathrm{a}}$ ), 3.65 (m, H-6" $\left.{ }_{\mathrm{b}}\right), 7.55(d, 8.0 \mathrm{~Hz}, \mathrm{NH}) ;{ }^{13} \mathrm{C}$ NMR (DMSO- $d_{6}$, $100 \mathrm{MHz}) \delta: 69.4$ (C-1), 50.3 (C-2), 70.9 (C-3), 71.3 (C-4), 34.8 (C-5), 129.8 (C-6), 130.1 (C-7), 27.4 (C-8/C-11'), 32.2 (C-9), 130.3 (C-10), 130.7 (C-11), 31.8 (C-12), 29.0-30.9 (C-13 to C-22), 22.6 (C-23/C-19'), 14.4 (Me-24/Me-20'), $174.2\left(\mathrm{C}-1^{\prime}\right), 71.3$ (C-2'), 34.8 (C-3'), 24.4 (C-4'/C-8'), 27.1 (C-5'), 130.1 (C-6'/C-10'), 129.8 (C-7'/C-9'), 29.0-30.9 (C-12' to C-18'), 103.9 (C-1"), 73.9 (C-2"), 76.9 (C-3"), 70.4 (C-4"), 77.3 (C-5"), $61.4\left(\mathrm{C}-6^{\prime \prime}\right)$; MALDI-FT-MS $m / z: 866.6720\left([\mathrm{M}+\mathrm{H}]^{+}, \mathrm{C}_{50} \mathrm{H}_{92} \mathrm{O}_{10} \mathrm{~N}\right)$, 
MALDI-FT-MS ${ }^{2}$ (CID at $45 \mathrm{eV}$ ) (rel. int.) $m / z: 704.6171$ $\left[(\mathrm{M}+\mathrm{H})-162, \quad \mathrm{C}_{44} \mathrm{H}_{82} \mathrm{NO}_{5}, \quad 51\right]^{+}, \quad 686.6065 \quad[(\mathrm{M}+\mathrm{H})-$ $\left.162-\mathrm{H}_{2} \mathrm{O}, \mathrm{C}_{44} \mathrm{H}_{80} \mathrm{NO}_{4}, \quad 70\right]^{+}, \quad 500.3176[(\mathrm{M}+\mathrm{H})-366$, $\left.\mathrm{C}_{26} \mathrm{H}_{46} \mathrm{NO}_{8}, 100\right]^{+}$.

\section{General experimental procedures}

IR spectra were recorded on a Bruker Alpha FT-IR spectrometer (Optik GmbH, Germany). UV spectra were recorded on Thermo Electron Helios spectrophotometer (UVB 120726, England).

${ }^{1} \mathrm{H}$ - and ${ }^{13} \mathrm{C}$-NMR spectra were recorded with a Bruker spectrometer at $500 \mathrm{MHz}$ and a Varian spectrometer at $400 \mathrm{MHz}$. Chemical shifts $(\delta)$ were quoted in parts per million ( $\mathrm{ppm})$ from the internal standard tetramethylsilane (TMS). Deuterated solvents as dimethyl sulfoxide (DMSO- $d_{6}$, for compounds $1,2,3,7$ and 8 ), and chloroform $\left(\mathrm{CDCl}_{3}\right.$, for compounds $\mathbf{4}, \mathbf{5}$ and $\left.\mathbf{6}\right)$ were used for the NMR experiments. Mass spectrometry was performed on a Thermo Scientific LTQ-Orbitrap instrument coupled to a MALDI (matrix-assisted laser desorption ionization) or liquid chromatography electrospray ionization source. Column chromatography was performed on MN silica gel 60 (0.063-0.2 mm/70-230) mesh. Preparative TLC was performed using high-purity grade silica gel powder $(60 \mathrm{~A}, 2-25 \mu \mathrm{m})$ Sigma-Aldrich, Germany. Pre-coated plates of TLC silica gel $60 \mathrm{~F}_{254}$ (Merck, Germany) were used for monitoring fractions and spots were detected with UV light (254 and $365 \mathrm{~nm})$ and then sprayed with $30 \% \mathrm{H}_{2} \mathrm{SO}_{4}$ followed by heating up to $110^{\circ} \mathrm{C}$.

\section{Antimicrobial assay}

The two-fold serial microdilution method described by Eloff (1998) was used to determine the minimum inhibitory concentration (MIC) values for the extract, fractions and isolated compounds against bacteria [7] and a modification of [7] by Masoko et al. (2005) was used for fungi [8]. The respective MIC of the samples was determined using two Gram-positive bacteria, Staphylococcus aureus (ATCC 29213) and Enterococcus faecalis (ATCC 29212), two Gram-negative bacteria, Pseudomonas aeruginosa (ATCC 27853) and Escherichia coli (ATCC 25922); and three clinical isolates of the pathogenic fungi Candida albicans, Cryptococcus neoformans and, Aspergillus niger along with Candida albicans (ATCC 10231). Some fungal strains used were cultured from clinical cases of fungal infectious diseases in animals (before treatment) in the Department of Veterinary Tropical Diseases, Faculty of Veterinary Science. C. albicans was isolated from a Gouldian finch, $C$. neoformans from a cheetah, while $A$. fumigatus was isolated from a chicken which suffered from a systemic mycosis.

In the antibacterial tests, $100 \mu \mathrm{l}$ of the $(10 \mathrm{mg} / \mathrm{ml})$ crude extract and fractions or $(1 \mathrm{mg} / \mathrm{ml})$ compounds in duplicate dissolved in dimethyl sulfoxide (DMSO) were serially diluted two-fold with sterile distilled water in 96well microtitre plates and $100 \mu \mathrm{l}$ bacterial culture in Mueller Hinton broth (MHB) (Fluka, Germany) was added to each well. DMSO was used to dissolve the compounds because acetone used in the original method [7] did not dissolve all the compounds well. The densities of bacterial cultures were approximately $2.6 \times 10^{12} \mathrm{cfu} / \mathrm{ml}$, $S$. aureus; $1.5 \times 10^{10} \mathrm{cfu} / \mathrm{ml}$, E. faecalis; $5.2 \times 10^{13} \mathrm{cfu} / \mathrm{ml}$, $P$. aeruginosa and $3.0 \times 10^{11} \mathrm{cfu} / \mathrm{ml}, E$. coli, obtained by adding $99 \mathrm{ml}$ of MHB to $1 \mathrm{ml}$ of each microorganism from the freshly prepared overnight bacterial culture in Mueller Hinton broth [9]. Gentamicin and DMSO were used as positive and negative controls, respectively. The microtitre plates were sealed in plastic bags to avoid contamination in the laboratory and were incubated overnight at $37^{\circ} \mathrm{C}$. Afterwards, $40 \mu \mathrm{l}$ of $0.2 \mathrm{mg} / \mathrm{ml}$ of $p$ iodonitrotetrazolium violet (INT) (Sigma, Germany) was added to each well to indicate microbial growth. The microtitre plates were further incubated at $37^{\circ} \mathrm{C}$ for $2 \mathrm{~h}$ and the minimal inhibitory concentration (MIC) was determined as the lowest concentration inhibiting microbial growth, indicated by a decrease in the intensity of the red colour of the formazan [10].

For the antifungal assay, $100 \mu \mathrm{l}$ of the crude extract, fractions and compounds dissolved in DMSO at the same concentrations, as described above for the bacteria, were two-fold serially diluted with distilled water in 96well microtitre plates, and $100 \mu \mathrm{l}$ of fungal culture in Potato Dextrose broth (Sigma, Germany) was added to each well [8]. Amphotericin B and DMSO were used as positive and negative controls, respectively. INT $(40 \mu \mathrm{l})$ at $0.2 \mathrm{mg} / \mathrm{ml}$ in distilled water was added to each well as a growth indicator and the covered microplates were incubated at $35^{\circ} \mathrm{C}$ after sealing in a plastic bag. The MIC value was recorded after 16 and $24 \mathrm{~h}$ incubation for $C$. albicans and A. fumigatus, and after 24 and $36 \mathrm{~h}$ incubation for C. neoformans as the lowest concentration of the sample that inhibited fungal growth. The colourless salt of tetrazolium acts as an electron acceptor and is reduced to a red coloured formazan product by biologically active organisms [11,12]. The solution in the well remains clear or shows a marked decrease in intensity of colour after incubation with INT at the concentration where fungal growth is inhibited. The experiment was performed in triplicate and the standard deviation was zero.

\section{Cytotoxicity assay}

The MTT (3-(4,5-dimethylthiazolyl-2)-2,5-diphenyltetrazolium bromide) reduction assay is one of the most frequently used methods for measuring cell proliferation and cytotoxicity. The intensity of colour (measured spectrophotometrically) of the MTT formazan produced by 
living, metabolically active cells is proportional to the number of live cells present. MTT is a yellow watersoluble tetrazolium dye that is reduced by live, but not dead, cells to a purple formazan product that is insoluble in aqueous solutions. The viable cell growth after incubation with extract, fractions and isolated compounds was determined using the tetrazolium-based colorimetric MTT assay described by Mosmann (1983) [13]. In short, monkey Vero cells of a subconfluent culture were harvested and centrifuged at $200 \times g$ for $5 \mathrm{~min}$, and resuspended in growth medium to $5 \times 10^{4}$ cells $/ \mathrm{ml}$. The growth medium used was Minimal Essential Medium (MEM, Sigma) supplemented with $0.1 \%$ gentamicin (Virbac) and 5\% foetal calf serum (Sigma). A total of $200 \mu \mathrm{l}$ of the cell suspension is pipetted into each well of columns 2 to 11 of a sterile 96-well microtitre plate. A $200 \mu \mathrm{l}$ aliquot of growth medium was added to wells of columns 1 and 12 to minimize the "edge effect" and maintain humidity. The plates were incubated for $24 \mathrm{~h}$ at $37^{\circ} \mathrm{C}$ in a $5 \% \mathrm{CO}_{2}$ incubator, until the cells were in the exponential phase of growth. The MEM was aspirated from the cells, and replaced with $200 \mu \mathrm{l}$ of extract, fractions and compounds at differing concentrations (serial dilution prepared in growth medium). The cells were disturbed as little as possible during the aspiration of medium and addition of test samples. Each dilution was tested in quadruplicate. The microtitre plates were incubated at $37^{\circ} \mathrm{C}$ in a $5 \% \mathrm{CO}_{2}$ incubator for $48 \mathrm{~h}$ with test compounds, fractions or extract. Untreated cells and positive control (doxorubicin, Pfizer Laboratories) were included. After incubation, cells were washed with $150 \mu \mathrm{l}$ phosphate buffered saline (PBS) and fresh MEM $(200 \mu \mathrm{l})$ was added to each well together with $30 \mu \mathrm{l}$ MTT (Sigma, stock solution of $5 \mathrm{mg} / \mathrm{ml}$ in PBS). The plates were then incubated for a further $4 \mathrm{~h}$ at $37^{\circ} \mathrm{C}$. After incubation with MTT the medium in each well was carefully removed, without disturbing the MTT crystals in the wells. The MTT formazan crystals were dissolved by adding $50 \mu \mathrm{l}$ DMSO to each well and the plates gently shaken until the MTT solution was dissolved. The amount of MTT reduction was measured immediately by detecting absorbance in a microplate reader (Versamax, Molecular Devices) at a wavelength of $570 \mathrm{~nm}$ and a reference wavelength of $630 \mathrm{~nm}$. The wells in column 1 , containing medium and MTT but no cells, were used to blank the plate reader. The $\mathrm{LC}_{50}$ values were calculated as the concentration of test sample resulting in a $50 \%$ reduction of absorbance compared to untreated cells.

\section{Results and discussion}

Chemical composition and antimicrobial activity

The EtOH crude extract from the twigs of Eriosema robustum was subjected to repeated silica gel column chromatography followed by preparative TLC and Sephadex LH-20 to afford eight compounds including robusflavones $\mathrm{A}\left(1\right.$, yellow amorphous, $\left.m / z 362, \mathrm{C}_{17} \mathrm{H}_{14} \mathrm{O}_{9}\right)$ and $\mathrm{B}$ (2, yellow amorphous, $m / z$ 332, $\mathrm{C}_{16} \mathrm{H}_{12} \mathrm{O}_{8}$ ) [4], orostachyscerebroside A (3) [14], stigmasterol (4, white powder, $m / z 412, \mathrm{C}_{29} \mathrm{H}_{48} \mathrm{O}$ ) [15], 1-O-heptatriacontanoyl glycerol (5, white powder, $m / z 484, \mathrm{C}_{30} \mathrm{H}_{60} \mathrm{O}_{4}$ ) [16], eicosanoic acid (6, white powder, $m / z 312, \mathrm{C}_{20} \mathrm{H}_{40} \mathrm{O}_{2}$ ) [17], 3-O- $\beta$-Dglucopyranoside of sitosterol (7, white crystals, $m / z$ $\mathrm{C}_{35} \mathrm{H}_{60} \mathrm{O}_{6}$ ) [18] and 6-prenylpinocembrin (8, yellow, $m / z \mathrm{C}_{20} \mathrm{H}_{20} \mathrm{O}_{4}$ ) [19] (Figure 1). The structures elucidation of the compounds were achieved by interpretation of their NMR, IR, UV and MS data, and by comparison with those reported in the literature. To the best of our knowledge this is the first report on the isolation of a cerebroside, orostachyscerebroside A (3), from the genus Eriosema. Orostachyscerebroside A (3) was found for the first time in the aerial parts of Orostachys japonicas in 2012 [14].

The antimicrobial activity and cytotoxicity of the crude extract, fractions from the column chromatography of the extract and isolated compounds (1-8) were determined and the results are presented in Tables 1, 2 and 3. Many authors consider the antimicrobial activity of extracts to be significant if the MIC value is $0.1 \mathrm{mg} / \mathrm{ml}$ or lower, moderate if $0.1<\mathrm{MIC} \leq 0.625 \mathrm{mg} / \mathrm{ml}$ and weak if $\mathrm{MIC}>0.625 \mathrm{mg} / \mathrm{ml}[20,21]$. When reporting the antimicrobial activity of the isolated compounds, it is significant if the MIC is $10 \mu \mathrm{g} / \mathrm{ml}$ or lower, moderate if $10<$ $\mathrm{MIC} \leq 100 \mu \mathrm{g} / \mathrm{ml}$ and low if MIC $>100 \mu \mathrm{g} / \mathrm{ml}[21,22]$. Based on these criteria, all the tested samples had significant to weak antifungal activities against the four fungi with MIC values between 80 and $1250 \mu \mathrm{g} / \mathrm{ml}$ (Table 1). Fraction B was significantly active against $A s$ pergillus fumigatus and Cryptoccocus neoformans with an MIC of $0.08 \mathrm{mg} / \mathrm{ml}$, while the crude extract and fraction A had moderate activity against Aspergillus fumigatus and Candida albicans (ATCC) with an MIC value of $0.16 \mathrm{mg} / \mathrm{ml}$ in all cases. Fraction B had the highest antifungal activity among the tested fractions and extract with an average MIC of $0.61 \mathrm{mg} / \mathrm{ml}$ followed by fraction A (average MIC of $0.65 \mathrm{mg} / \mathrm{ml}$ ) and the crude extract (average MIC of $0.88 \mathrm{mg} / \mathrm{ml}$ ).

The most active isolated compounds had moderate antifungal activity with the MIC value of $65 \mu \mathrm{g} / \mathrm{ml}$. These included robusflavones A (1) and B (2) against C. albicans (ATCC) and A. fumigatus, compounds 4 and 7 against $C$. albicans (ATCC), as well as compound $\mathbf{6}$ against $A$. fumigatus and C.neoformans, orostachyscerebroside A (3) against A. fumigatus, and robusflavone B (2) against $C$. neoformans. Compounds 5 and 7 had weak antifungal activity against C. neoformans (MIC > $250 \mu \mathrm{g} / \mathrm{ml}$ in both cases). The animal pathogenic isolate C. albicans was more resistant to the tested samples with MIC values between 0.63 to $1.25 \mathrm{mg} / \mathrm{ml}$ for the 
<smiles>[R7]Oc1c(-c2cc(O)c(OC)c([R2])c2O)oc2cc(O)cc(O)c2c1=O</smiles>

extract and fractions and ranging from 125 to $250 \mu \mathrm{g} / \mathrm{ml}$ for compounds, respectively. Nevertheless, robusflavone B (2) had the best antifungal activity (average MIC of $88 \mu \mathrm{g} / \mathrm{ml}$ ), followed by compounds 3 and $\mathbf{6}$ (average MIC of $110 \mu \mathrm{g} / \mathrm{ml}$ ), compound 7 (average MIC of $157 \mu \mathrm{g} / \mathrm{ml}$ ) and robusflavone A (1) (average MIC of $165 \mu \mathrm{g} / \mathrm{ml}$ ).

The antibacterial activity of the crude extract, fractions and isolated compounds were determined against four bacteria with MIC values ranging from 0.02 to $0.31 \mathrm{mg} / \mathrm{ml}$ and from 31.3 to $250 \mu \mathrm{g} / \mathrm{ml}$, respectively (Table 1 ). The crude extract had good activity against $S$. aureus, E. faecalis and E. coli (MIC value of $0.08 \mathrm{mg} / \mathrm{ml}$ ) and had moderate activity against $P$. aeruginosa (MIC value of $0.31 \mathrm{mg} / \mathrm{ml})$. Fraction A had excellent activity against $S$. aureus (MIC of $0.02 \mathrm{mg} / \mathrm{ml}$ ), E. faecalis and E. coli (MIC of $0.04 \mathrm{mg} / \mathrm{ml}$ ) and reasonable activity against $P$. aeruginosa (MIC value of $0.31 \mathrm{mg} / \mathrm{ml}$ ). The Gram-negative $P$. aeruginosa and the Gram-positive $S$. aureus were more resistant to fraction B with MIC values of 0.31 and $0.16 \mathrm{mg} / \mathrm{ml}$, respectively. However, fraction B had significant activity against $E$. faecalis and $E$. coli with an MIC value of $0.08 \mathrm{mg} / \mathrm{ml}$. Compound $\mathbf{8}$ had moderate activity against $S$. aureus (MIC value of $31.3 \mu \mathrm{g} / \mathrm{ml}$ ) and had reasonable activity against other bacteria with an MIC value of $63 \mu \mathrm{g} / \mathrm{ml}$. Other constituents had also reasonable antibacterial activity against $P$. aeruginosa with the MIC value of $63 \mu \mathrm{g} / \mathrm{ml}$ as well as robusflavone B (2) and compound 6 against E. faecalis (MIC of $63 \mu \mathrm{g} / \mathrm{ml}$ ). Amongst all the isolated compounds, 6-prenylpinocembrin (8) had the highest antibacterial activity with an average MIC of $55.1 \mu \mathrm{g} / \mathrm{ml}$ and average total activity of $20 \mathrm{ml} / \mathrm{mg}$ followed by robusflavone B (2), and compounds 5 and $\mathbf{6}$ (average MIC of $94 \mu \mathrm{g} / \mathrm{ml}$ and average total activity of $12 \mathrm{ml} / \mathrm{mg}$ ), as well as robusflavone A (1) with an average MIC of $203.3 \mu \mathrm{g} / \mathrm{ml}$ and average total activity of $7 \mathrm{ml} / \mathrm{mg}$.

The crude extract and fractions were found to be more active than the isolated compounds against the bacteria and the fungi. The antibacterial activity of fraction $\mathrm{A}$ is 
Table 1 Minimum inhibitory concentration (MIC) of the extract, fractions and compounds (1-8) from E. robustum against fungi (C.a, C.A, A.f, C.n) and bacteria (S.a, P.a, E.f, E.c)

\begin{tabular}{|c|c|c|c|c|c|c|c|c|c|c|c|c|c|c|}
\hline \multirow[t]{3}{*}{ Samples } & \multicolumn{9}{|c|}{ Fungi (MIC values) } & \multicolumn{5}{|c|}{ Bacteria (MIC values) } \\
\hline & \multicolumn{2}{|c|}{ C.a } & \multicolumn{2}{|c|}{ C.A } & \multicolumn{2}{|c|}{ A.f } & \multicolumn{2}{|c|}{ C. $n^{a}$} & \multirow[t]{2}{*}{ Average } & \multirow[t]{2}{*}{ S.a } & \multirow[t]{2}{*}{ P.a } & \multirow[t]{2}{*}{ E.f } & \multirow[t]{2}{*}{ E.c } & \multirow[t]{2}{*}{ Averag } \\
\hline & $16 \mathrm{~h}$ & $24 \mathrm{~h}$ & $16 \mathrm{~h}$ & $24 \mathrm{~h}$ & $16 \mathrm{~h}$ & $24 \mathrm{~h}$ & $24 \mathrm{~h}$ & $36 \mathrm{~h}$ & & & & & & \\
\hline \multicolumn{15}{|l|}{ Extract and Fractions $(\mathrm{mg} / \mathrm{ml})$} \\
\hline Crude extract & 1.25 & 1.25 & 1.25 & 1.25 & 0.16 & 0.63 & 0.63 & 0.63 & 0.88 & 0.08 & 0.31 & 0.08 & 0.08 & 0.14 \\
\hline Fraction A & 0.63 & 0.63 & 0.16 & 0.32 & 0.32 & 0.63 & 1.25 & 1.25 & 0.65 & 0.02 & 0.31 & 0.04 & 0.04 & 0.10 \\
\hline Fraction B & 1.25 & 1.25 & 0.32 & 0.63 & 0.08 & 0.63 & 0.08 & 0.63 & 0.61 & 0.16 & 0.31 & 0.08 & 0.08 & 0.16 \\
\hline \multicolumn{15}{|l|}{ Compounds $(\mu \mathrm{g} / \mathrm{ml})$} \\
\hline Robusflavone A (1) & 250 & 250 & 65 & 65 & 65 & 125 & 250 & 250 & 165 & 250 & 63 & 250 & 250 & 203.3 \\
\hline Robusflavone B (2) & 125 & 125 & 65 & 65 & 65 & 125 & 65 & 65 & 88 & 125 & 63 & 63 & 125 & 94 \\
\hline Orostachyscerebroside A (3) & 250 & 250 & 130 & 250 & 130 & 250 & 250 & 250 & 220 & 125 & 63 & 125 & 125 & 109.5 \\
\hline Stigmasterol (4) & 125 & 125 & 125 & 125 & 65 & 65 & 125 & 125 & 110 & 125 & 63 & 250 & 250 & 172 \\
\hline 1-O-Heptatriacontanoyl glycerol (5) & 250 & 250 & 65 & 65 & 125 & 125 & 250 & 250 & 173 & 125 & 63 & 125 & 125 & 109.5 \\
\hline Eicosanoic acid (6) & 250 & 250 & 125 & 125 & 125 & 125 & $>250$ & $>250$ & 188 & 63 & 63 & 125 & 125 & 94 \\
\hline 3-O- $\beta$-D-Glucopyranoside of sitosterol (7) & 125 & 125 & 125 & 125 & 65 & 125 & 65 & 125 & 110 & 125 & 63 & 63 & 125 & 94 \\
\hline 6-Prenylpinocembrin (8) & 125 & 125 & 65 & 65 & 125 & 250 & $>250$ & $>250$ & 157 & 31.3 & 63 & 63 & 63 & 55.1 \\
\hline \multicolumn{15}{|l|}{ Controls $(\mu \mathrm{g} / \mathrm{ml})$} \\
\hline Amp B & 30 & 30 & 10 & 30 & 65 & 125 & $>250$ & $>250$ & 99 & - & - & - & - & - \\
\hline Gen & - & - & - & - & - & - & - & - & - & $<3.91$ & $<3.91$ & $<3.91$ & $<3.91$ & $<3.91$ \\
\hline $\mathrm{DMSO}^{\mathrm{b}}$ & na & na & na & na & na & na & na & na & & na & na & na & na & \\
\hline
\end{tabular}

C.a: Candida albicans (isolate), C.A: Candida albicans (ATCC), C.n: Cryptococcus neoformans, A.f: Aspergillus fumigatus, E.c: Escherichia coli, E.f: Enterococcus faecalis,

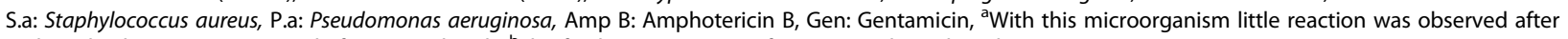
$16 \mathrm{~h}$ and values were measured after 24 and $36 \mathrm{~h},{ }^{\mathrm{b}}$ The final concentration of DMSO used was less than $10 \%$, na: not active.

The results are the means of three replicates for fungi and two replicates for bacteria and the standard deviation was zero.

Table 2 Total activity in $\mathrm{ml} / \mathrm{g}$ of crude extract and fractions ( $A$ and $B$ ) from $E$. robustum calculated by dividing mass in $\mathrm{g}$ of extract or fractions with their MIC values [20]

\begin{tabular}{|c|c|c|c|c|c|c|c|c|c|c|c|c|c|c|}
\hline \multirow[t]{3}{*}{ Samples } & \multicolumn{9}{|c|}{ Fungi } & \multicolumn{5}{|c|}{ Bacteria } \\
\hline & \multicolumn{2}{|c|}{ C.a } & \multicolumn{2}{|c|}{ C.A } & \multicolumn{2}{|c|}{ A.f } & \multicolumn{2}{|c|}{ C.n } & \multirow[t]{2}{*}{ Average } & \multirow[t]{2}{*}{ S.a } & \multirow[t]{2}{*}{ P.a } & \multirow[t]{2}{*}{ E.f } & \multirow[t]{2}{*}{ E.c } & \multirow[t]{2}{*}{ Average } \\
\hline & $16 \mathrm{~h}$ & $24 \mathrm{~h}$ & $16 \mathrm{~h}$ & $\overline{24 h}$ & $16 \mathrm{~h}$ & $\overline{24 h}$ & $24 \mathrm{~h}$ & $\overline{36 h}$ & & & & & & \\
\hline \multicolumn{15}{|l|}{ Extract and Fractions } \\
\hline Crude extract & 4000 & 4000 & 4000 & 4000 & 31250 & 7937 & 7937 & 7937 & 8883 & 62500 & 16129 & 62500 & 62500 & 50907 \\
\hline Fraction A & 1429 & 1429 & 5625 & 2813 & 2813 & 1429 & 720 & 720 & 2123 & 45000 & 2903 & 22500 & 22500 & 23226 \\
\hline Fraction B & 560 & 560 & 2188 & 1111 & 8750 & 1111 & 8750 & 1111 & 3018 & 4375 & 2258 & 8750 & 8750 & 6033 \\
\hline \multicolumn{15}{|l|}{ Compounds } \\
\hline Robusflavone A (1) & 4 & 4 & 13.4 & 13.4 & 13.4 & 8 & 4 & 4 & 8 & 4 & 16 & 4 & 4 & 7 \\
\hline Robusflavone B (2) & 8 & 8 & 13.4 & 13.4 & 13.4 & 8 & 13.4 & 13.4 & 11 & 8 & 16 & 16 & 8 & 12 \\
\hline Orostachyscerebroside A (3) & 4 & 4 & 7.7 & 4 & 7.7 & 4 & 4 & 4 & 4.5 & 8 & 16 & 8 & 8 & 9.1 \\
\hline Stigmasterol (4) & 8 & 8 & 8 & 8 & 13.4 & 13.4 & 8 & 8 & 9 & 8 & 16 & 4 & 4 & 8 \\
\hline 1-O-Heptatriacontanoyl glycerol (5) & 4 & 4 & 13.4 & 13.4 & 8 & 8 & 4 & 4 & 7 & 8 & 16 & 8 & 8 & 10 \\
\hline Eicosanoic acid (6) & 4 & 4 & 8 & 8 & 8 & 8 & $<8$ & $<8$ & 7 & 16 & 16 & 8 & 8 & 12 \\
\hline 3-O-ß-D-Glucopyranoside of sitosterol (7) & 8 & 8 & 8 & 8 & 13.4 & 8 & 13.4 & 8 & 9 & 8 & 16 & 16 & 8 & 12 \\
\hline 6-Prenylpinocembrin (8) & 8 & 8 & 13.4 & 13.4 & 8 & 4 & $<4$ & $<4$ & 8 & 32 & 16 & 16 & 16 & 20 \\
\hline
\end{tabular}

C.a: Candida albicans (isolate), C.A: Candida albicans (ATCC), C.n: Cryptococcus neoformans, A.f: Aspergillus fumigatus, E.c: Escherichia coli, E.f: Enterococcus faecalis, S.a: Staphylococcus aureus, P.a: Pseudomonas aeruginosa.

The inverse of MIC in $\mathrm{ml} / \mathrm{mg}$ was calculated for compounds (1-8). 
Table 3 Cytotoxicity of the crude extract, fractions and compounds from E. robustum and their selectivity index (SI)

\begin{tabular}{|c|c|c|c|c|c|c|c|c|c|}
\hline \multirow[t]{2}{*}{ Samples } & \multirow[t]{2}{*}{ Cytotoxicty $\left(\mathrm{LC}_{50}, \mu \mathrm{g} / \mathrm{ml}\right)$} & \multicolumn{8}{|c|}{ Selectivity index ${ }^{a}$} \\
\hline & & C.a & C.A & A.f & C.n & S.a & P.a & E.f & E.c \\
\hline \multicolumn{10}{|l|}{ Extract and fractions } \\
\hline Crude extract & $53.45 \pm 2.21$ & 0.04 & 0.04 & $0.21^{*}$ & 0.08 & 0.67 & 0.17 & 0.67 & 0.67 \\
\hline Fraction A & $17.91 \pm 1.71$ & 0.03 & $0.09^{*}$ & $0.05^{*}$ & 0.01 & 0.90 & 0.06 & 0.45 & 0.45 \\
\hline Fraction B & $93.76 \pm 25.62$ & 0.08 & $0.22^{*}$ & $0.66^{*}$ & $0.66^{*}$ & 0.59 & 0.30 & 1.17 & 1.17 \\
\hline \multicolumn{10}{|l|}{ Compounds } \\
\hline Robusflavone A (1) & $13.20 \pm 0.02$ & 0.05 & 0.20 & $0.16^{*}$ & 0.05 & 0.05 & 0.21 & 0.05 & 0.05 \\
\hline Robusflavone B (2) & $30.42 \pm 3.26$ & 0.24 & 0.47 & $0.36^{*}$ & 0.47 & 0.24 & 0.48 & 0.48 & 0.24 \\
\hline Orostachyscerebroside A (3) & $>100$ & 0.4 & $0.53^{*}$ & $0.53^{*}$ & 0.4 & 0.8 & 1.59 & 0.8 & 0.8 \\
\hline Stigmasterol (4) & $54.97 \pm 11.05$ & 0.44 & 0.44 & 0.85 & 0.44 & 0.44 & 0.87 & 0.22 & 0.22 \\
\hline 1-O-Heptatriacontanoylglycerol (5) & $91.52 \pm 28.38$ & 0.37 & 1.41 & 0.73 & 0.37 & 0.73 & 1.45 & 0.73 & 0.73 \\
\hline Eicosanoic acid (6) & NT & - & - & - & - & - & - & - & - \\
\hline 3-O- $\beta$-D-Glucopyranoside of sitosterol (7) & $>100$ & 0.80 & 0.80 & $1.17^{*}$ & $1.17^{*}$ & 0.80 & 1.58 & 1.58 & 0.80 \\
\hline 6-Prenylpinocembrin (8) & $21.87 \pm 0.37$ & 0.17 & 0.34 & $0.13^{*}$ & 0.09 & 0.70 & 0.35 & 0.35 & 0.35 \\
\hline \multicolumn{10}{|l|}{ Control } \\
\hline Dox & $3.32 \pm 1.31$ & & & & & & & & \\
\hline
\end{tabular}

C.a: Candida albicans (isolate), C.A: Candida albicans (ATCC), A.f: Apergillus fumigatus, C.n: Cryptoccocus neoformans, E.c: Escherichia coli, E.f: Enterococcus faecalis, S.a: Staphylococcus aureus, P.a: s Dox: Doxorubicin with $\mathrm{LC}_{50}$ in $\mu \mathrm{M}$, NT: not tested, ${ }^{a} \mathrm{SI}=\mathrm{LC}_{50} / \mathrm{MIC}$, *SI obtained from average MIC.

noteworthy against the bacteria with an average MIC value of $100 \mu \mathrm{g} / \mathrm{ml}[20,23]$ and an average total activity of $23226 \mathrm{ml} / \mathrm{g}$. Fraction B had good antifungal activity against $A$. fumigatus and $C$. neoformans with an MIC value of $80 \mu \mathrm{g} / \mathrm{ml}$ and total activity of $8750 \mathrm{ml} / \mathrm{g}$ after 16 and $24 \mathrm{~h}$ of incubation. This implies that if $1 \mathrm{~g}$ of fraction $B$ from the ethanol extract was diluted to 8.75 litres it would still inhibit the growth of $A$. fumigatus and $C$. neoformans. Compound $\mathbf{8}$, obtained from the most antibacterial-active part, fraction $\mathrm{A}$, had the highest antibacterial activity amongst all the isolated compounds with an average MIC of $55.1 \mu \mathrm{g} / \mathrm{ml}$ and average total activity of $20 \mathrm{ml} / \mathrm{mg}$. The antibacterial activity of compound $\mathbf{8}$ is in agreement with previous results reported on the antimicrobial activity of similar compounds bearing the prenyl group on their structures $[6,24]$. Robusflavones A (1) and B (2) characterized earlier as two new antioxidant flavones [4] had moderate activities against fungi and bacteria with mean MIC values of $165,88,203.3$ and $94 \mu \mathrm{g} / \mathrm{ml}$, and average total activities of $8,11,7$ and $12 \mathrm{ml} / \mathrm{mg}$, respectively. The cerebroside and the glycerol derivative (compounds 3 and 5) had similar antibacterial activity (both with average MIC of $109.5 \mu \mathrm{g} / \mathrm{ml}$ ) but had slightly different antifungal activity with average MIC values of 220 and $173 \mu \mathrm{g} / \mathrm{ml}$, respectively.

From the results, it is evident that the isolated compounds did not have good activity against the tested microorganisms as observed for extract and fractions. This supports the conclusion of Lewis and Ausubel (2006) that plants contain many compounds with low antimicrobial activity and use other mechanisms to combat microbial growth [25]. In some of our previous work, it has been found that crude extracts and fractions have excellent potential activity in treating microbial infections and may even have as good or higher activity than commercially used antimicrobials in the field or clinical trials [26,27]. This could be justified by the fact that, constituents in plant extract or fractions interacting in a synergistic manner may not be highly active when they are not part of a mixture with synergistic compounds. The antimicrobial activity of the crude extract, fractions and compounds $(\mathbf{1 - 3}, \mathbf{5}, \mathbf{6}$ and $\mathbf{8})$ are reported here for the first time.

\section{Cytotoxicity}

The crude extract, fractions and isolated compounds from the twigs of $E$. robostum were evaluated for their cytotoxicity against monkey kidney Vero cells in vitro using the MTT (3-(4,5-dimethylythiazol-2-yl)-2,5-diphenyl-2H-tetrazolium hydrobromide) assay and the results are presented in Table 3. Apart from eicosanoic acid (6) that was not tested, compounds 3 and 7 had $\mathrm{LC}_{50}$ value greater than $100 \mu \mathrm{g} / \mathrm{ml}$ whilst the crude extract, fractions and others isolated compounds $(\mathbf{1}, \mathbf{2}, \mathbf{4}, 5$ and $\mathbf{8})$ had cytotoxic activity against the Vero cells with $\mathrm{LC}_{50}$ values ranging from 13.20 to $91.52 \mu \mathrm{g} / \mathrm{ml}$. Our samples, and especially the tested compounds, could be considered less toxic than the positive control doxorubicin $\left(\mathrm{LC}_{50}=3.32 \mu \mathrm{M}\right)$ and by taking into consideration the criterion of the American National Cancer Institute (NCI) regarding the cytotoxicity of pure compounds 
$\left(\mathrm{LC}_{50}<4 \mu \mathrm{g} / \mathrm{ml}\right)$ [28]. However, the $\mathrm{LC}_{50}$ values of 13.20 , 30.42 and $21.87 \mu \mathrm{g} / \mathrm{ml}$ for compounds $\mathbf{1}, 2$ and $\mathbf{8}$ with the same basic skeleton (flavonoid) were lower than those of others compounds and more cell lines should be tested in a comprehensive screen to confirm their probable safety in terms of cytotoxicity. The selectivity index (SI) values of the tested samples ranged from 0.01 to 1.58 and could be considered as poor when taking in consideration that the ratio for a good therapeutic index for a remedy or drug should be $\geq 10$ [29]. This is the first report on the cytotoxicity of the extract, fractions as well as compounds $\mathbf{1}, \mathbf{2}, \mathbf{3}, \mathbf{5}$ and $\mathbf{8}$ from $E$. robustum against Vero cells.

Fraction B had good antifungal activity with a total activity of $3018 \mathrm{ml} / \mathrm{g}$ for the fraction. One should keep in mind that the $5 \mathrm{~g}$ of extract separated by column chromatography was obtained from $87 \mathrm{~g}$ of the original dried plant material. In comparing the activity of different plants the concept of total activity was developed [30]. This indicates the volume to which level the extract from $1 \mathrm{~g}$ of dried plant material can be diluted and still inhibit the growth of the microorganism. The total activity of $3018 \mathrm{ml} / \mathrm{g}$ for fraction B was derived from $87 \mathrm{~g}$ of the original dried plant material. The total activity per gram dried plant material for fungi was therefore c. $35 \mathrm{ml} / \mathrm{g}$. The same argument shows that fraction A had a total antibacterial activity of $267 \mathrm{ml} / \mathrm{g}$ dried plant material. The crude extract and fractions had fungistatic effect in most of the cases such as the crude extract against $A$. fumigatus, fraction A against $C$. albicans and A. fumigatus, and fraction B against C. albicans, A. fumigatus and $C$. neoformans. It is noteworthy that the crude extract had a fungicidal activity against the two Candida and the Cryptococcus species, but the fractions had mainly fungistatic activity. This again points to the probability of synergistic activities.

With the high total activity of the crude extract and the ease of preparation, there is a reasonable possibility that the crude extract can be used as topical treatment for fungal and especially bacterial infections. Manipulation of the extract by for example solvent-solvent fractionation may lead to extracts with a higher activity and possibly a lower cytotoxicity [31].

\section{Conclusion}

The results obtained support the traditional use of $E$. robustum to treat infections. The crude extract had good activity with low toxicity to animal cells, and may be useful in topical applications to combat microbial infections.

\section{Competing interests}

The authors declare that they have no competing interests.

\section{Authors' contributions}

MDA carried out the phytochemical and antimicrobial studies, and wrote the manuscript; LJM carried out the cytotoxicity and participated in the manuscript writing; SG and RM assisted with the structure elucidation of some compounds; PT, MS and JNE supervised the work. All the authors read and approved the final manuscript after revision by JNE.

\section{Acknowledgements}

The authors are grateful to the University of Pretoria for the Post-doctoral Fellowship awarded to MD Awouafack to work at the Faculty of Veterinary Science, Department of Paraclinical Sciences, Phytomedicine Programme, and the National Research Foundation and Medical Research Council for research funding.

\section{Author details}

'Phytomedicine Programme, Department of Paraclinical Sciences, Faculty of Veterinary Science, University of Pretoria, Private Bag X04, Onderstepoort 0110 , South Africa. 'Laboratory of Natural Products Chemistry, Department of Chemistry, Faculty of Science, University of Dschang, P.O. Box 67, Dschang, Cameroon. ${ }^{3}$ Institut für Umweltforschung (INFU) der Fakultät Chemie, Lehrstuhl für Umweltchemie und Analytische Chemie, Technische Universität Dortmund, Otto-Hahn-Strasse 6, D-44221 Dortmund, Germany.

Received: 27 April 2013 Accepted: 25 October 2013

Published: 29 October 2013

\section{References}

1. Ogungbamila O: Investigation of anti-infective activities of local plant materials used as drugs. In Results, lessons learned, and prospects for development of sustainable research environments in developing countries. Edited by Niemeyer HM. Santiago: IPICS; 1997

2. Gillett JB, Polhill RM, Verdcourt B: Papilionoideae. In Flora of Tropical East Africa, Leguminosae. Part 4th edition. Edited by Milne-Redhead E, Polhill RM. London: Crown Agents for Overseas Governments and Administrations; 1971:635-637.

3. Kokwaro JO: Medicinal plants of East Africa. 3rd edition. Nairobi: University of Nairobi Press; 2009:335

4. Awouafack MD, Tane P, Eloff JN: Two new antioxidant flavones from the twigs of Eriosema robustum (Fabaceae). Phytochemistry Lett 2013, 6:62-66.

5. Awouafack MD, Spiteller P, Lamshöft M, Kusari S, Ivanova B, Tane P, Spiteller M: Antimicrobial isopropenyl-dihydrofuranoisoflavones from Crotalaria lachnophora. J Nat Prod 2011, 74:272-278.

6. Awouafack MD, Kouam SF, Hussain H, Ngamga D, Tane P, Schulz B, Green IR, Krohn K: Antimicrobial prenylated dihydrochalcones from Eriosema glomerata. Planta Med 2008, 74:50-54.

7. Eloff JN: A sensitive and quick microplate method to determine the minimal inhibitory concentration of plant extracts for bacteria. Planta Med 1998, 64:711-713.

8. Masoko P, Picard J, Eloff JN: Antifungal activities of six South African Terminalia species (Combretaceae). J Ethnopharmacol 2005, 99:301-308.

9. Suleiman MM, McGaw $\sqcup$, Naidoo V, Eloff JN: Evaluation of several tree species for activity against the animal fungal pathogen Aspergillus fumigatus. S Afr J Bot 2010, 76:64-71.

10. Shai LJ, McGaw LJ, Masoko P, Eloff JN: Antifungal and antibacterial activity of seven traditionally used South African plant species active against Candida albicans. S Afr J Bot 2008, 74:677-684.

11. Mahlo SM, McGaw LJ, Eloff JN: Antifungal activity of leaf extracts from South African trees against plant pathogens. Crop Prot 2010, 29:1529-1533.

12. Eloff $\mathrm{JN}$ : Which extractant should be used for the screening and isolation of antimicrobial components from plants? J Ethnopharmacol 1998, 60:1-8.

13. Mosmann T: Rapid colorimetric assay for cellular growth and survival: application to proliferation and cytotoxicity assays. J Immunol Methods 1983, 65:55-63.

14. Zhang H, Oh J, Jang T, Min BS, Na M: Glycolipids from the aerial parts of Orostachys japonicus with fatty acid synthase inhibitory and cytotoxic activities. Food Chem 2012, 131:1097-1103.

15. Forgo $P$, Kövér KE: Gradient enhanced selective experiments in the ${ }^{1} \mathrm{H}$ NMR chemical shift assignment of the skeleton and side-chain resonances of stigmasterol, a phytosterol derivative. Steroids 2004, 69:43-50. 
16. Qi S-H, Zhang S, Huang J-S, Xiao Z-H, Wu J, Long L-J: Glycerol derivatives and sterols from Sargassum parvivesiculosum. Chem Pharm Bull 2004, 52:986-988

17. Jain R, Sharma P, Bhagchandani T, Jain SC: Phytochemical investigation and antimicrobial activity of Acacia senegal root heartwood. J Pharm Res 2012, 5:4934-4938.

18. Al-Ogail M, Hassan WHB, Ahmad MS, Al-Rehaily AJ: Phytochemical and biological studies of Solanum schimperianum Hochst. Saudi Pharm J 2012, 20:371-379.

19. Caffaratti M, Ortega MG, Scarafia ME, Ariza Espinar L, Juliani HR: Prenylated flavanones from Dalea elegans. Phytochemistry 1994, 36:1082-1084.

20. Eloff JN: Quantification the bioactivity of plant extracts during screening and bioassay guided fractionation. Phytomedicine 2004, 11:370-371.

21. Kuete V: Potential of Cameroonian plants and derived products against microbial infections: a review. Planta Med 2010, 76:1479-1491.

22. Ríos JL, Recio MC: Medicinal plants and antimicrobial activity. J Ethnopharmacol 2005, 100:80-84.

23. Kuete V, Ango PY, Fotso GW, Kapche GDWF, Dzoyem JP, Wouking AG, Ngadjui BT, Abegaz BM: Antimicrobial activities of the methanol extract and compounds from Artocarpus communis (Moraceae). BMC Complement Altern Med 2011, 11:42.

24. Awouafack MD, Kusari S, Lamshöft M, Ngamga D, Tane P, Spiteller M: Semi-synthesis of dihydrochalcone derivatives and their in Vitro antimicrobial activities. Planta Med 2010, 76:640-643.

25. Lewis K, Ausubel FM: Prospects for plant derived antibacterials. Nat Biotechnol 2006, 24:1504-1507.

26. Eloff JN, Angeh I, McGaw L: A potentised leaf extract of Melianthus comosus has higher activity than six commercial products used against plant fungal pathogens. S Afr J Bot 2007, 73:286-287.

27. Eloff JN, Suleiman M, Naidoo V: A crude extract of Loxostylus alata is as effective in treating aspergillosis in poultry as a commercial drug. Planta Med 2010, 76:405.

28. Tanamatayarat $P$, Limtrakul $P$, Chunsakaow S, Duangrat C: Screening of some Rubiaceous plants for cytotoxic activity against Cervix Carcinoma (KB-3-1) Cell Line. Thai J Pharm Sci 2003, 27:167-172.

29. Caamal-Fuentes E, Torres-Tapia LW, Simá-Polanco P, Peraza-Sánchez SR, Moo-Puc R: Screening of plants used in Mayan traditional medicine to treat cancer-like symptoms. J Ethnopharmacol 2011, 135:719-724.

30. Eloff JN: A proposal on expressing the antibacterial activity of plant extracts - a small first step in applying scientific knowledge to rural primary health care in South Africa. S Afr J Sci 2000, 96:116-118.

31. Eloff JN, Famakin JO, Katerere DRP: Combretum woodii (Combretaceae) leaf extracts have high activity against Gram-negative and Gram-positive bacteria. Afr J Biotechnol 2005, 4:1161-1166.

doi:10.1186/1472-6882-13-289

Cite this article as: Awouafack et al: Antimicrobial activity and cytotoxicity of the ethanol extract, fractions and eight compounds isolated from Eriosema robustum (Fabaceae). BMC Complementary and Alternative Medicine 2013 13:289.

\section{Submit your next manuscript to BioMed Central and take full advantage of:}

- Convenient online submission

- Thorough peer review

- No space constraints or color figure charges

- Immediate publication on acceptance

- Inclusion in PubMed, CAS, Scopus and Google Scholar

- Research which is freely available for redistribution 